
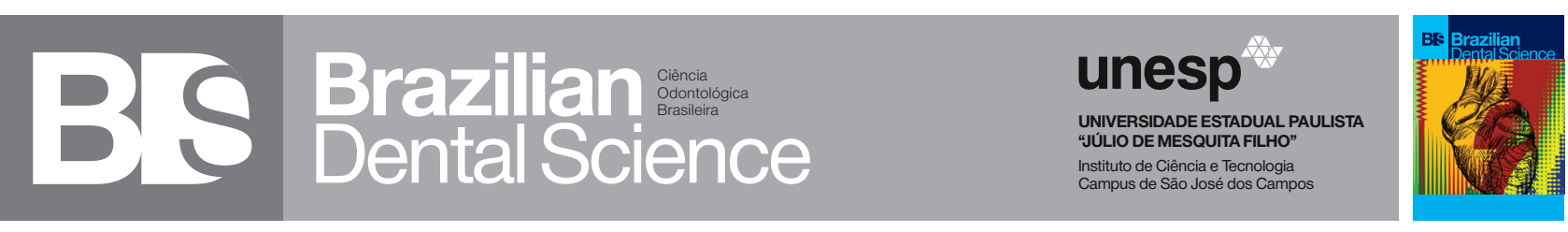

\title{
Effect of different concentrations of nanohydroxyapatite on tooth bleaching effectiveness and enamel bond strength
}

Efeito de diferentes concentrações de nanohidroxiapatita na efetividade clareadora e força de adesão ao esmalte

\author{
Laura Nobre FERRAZ ${ }^{1}$, Waldemir Francisco VIEIRA JÚNIOR¹, Gláucia Maria Bovi AMBROSANO², Maria Cecília Caldas GIORGI ${ }^{3}$, \\ Flávio Henrique Baggio AGUIAR ${ }^{1}$, Débora Alves Nunes Leite LIMA ${ }^{1}$ \\ 1 - Department of Restorative Dentistry - Piracicaba Dental School - University of Campinas - Piracicaba - SP - Brazil. \\ 2 - Department of Social Dentistry - Piracicaba Dental School - University of Campinas - Piracicaba - SP - Brazil. \\ 3 - Department of Operative Dentistry - School of Health Sciences - Amazonas State University - Manaus - AM - Brazil.
}

\begin{abstract}
Objective: To evaluate the effect of $35 \%$ hydrogen peroxide (35\% HP) combined to different concentrations of nanohydroxyapatite (nHA) on the effectiveness of dental bleaching (superficial enamel and deep dentin) and enamel bond strength. Material and Methods: Fifty bovine dental specimens $(5 \times 5 \times 2 \mathrm{~mm})$ were divided into 5 groups, according to the treatments $(\mathrm{n}=10)$ : no bleaching (negative control); 35\% HP (positive control); 35\% HP+ $5 \%$ nHA; $35 \%$ HP + 10\% nHa; and 35\% HP + 15\% nHA. Three in-office bleaching sessions were made. The color analysis was performed on the enamel surface and the opposite dentin, using a spectrophotometer. The results were expressed in the CIE L*a*b* system. After this, the adhesive system was applied to the tooth structure, and the dental specimens received a composite restoration. The microshear bond strength test was performed $24 \mathrm{~h}$ after the restoration. Data were submitted to ANOVA and Tukey's test $(\alpha=0.05)$. Results: For the enamel color analysis, all bleached groups differed statistically from the unbleached group, with increasing $L^{*}$ values and decreasing $b *$ values. The addition of different concentrations of nHA did not interfere with the bleaching effectiveness for the enamel and opposite dentin. For microshear bond strength, no statistically significant differences were presented between groups. The adhesive failure rate of the 35\% HP $+10 \%$ nHA group was lower than the $35 \%$ HP group and similar to the negative control. Conclusion: The addition of different concentrations of nHA in 35\% of hydrogen peroxide did not interfere with the bleaching efficacy of enamel and deep dentin and did not affect the enamel bond strength after bleaching.
\end{abstract}

\section{KEYWORDS}

Enamel; Shear strength; Tooth bleaching.

\section{RESUMO}

Objetivo: avaliar o efeito do peróxido de hidrogênio a 35\% (HP 35\%) associado a diferentes concentrações de nanohidroxiapatita (nHA) sobre a efetividade clareadora do esmalte superficial, dentina profunda e da força de adesão ao esmalte. Material e Métodos: Cinquenta espécimes bovinos $(5 \times 5 \times 2 \mathrm{~mm})$ foram divididos 5 grupos $(\mathrm{n}=$ 10): sem clareamento (controle negativo); HP 35\% (controle positivo); HP 35\% + nHA 5\%; HP 35\% + nHA 10\%; e HP 35\% + nHA 15\%. Três sessões de clareamento de consultório foram realizadas. A análise de cor foi realizada na superfície do esmalte e na dentina oposta e os resultados expressos no sistema CIE L*a*b*. Depois disso, os sistemas adesivos foram aplicados no esmalte, e os blocos receberam uma restauração em resina composta. $\mathrm{O}$ teste microcisalhamento foi realizado $24 \mathrm{~h}$ após a restauração. Os dados foram submetidos à ANOVA e ao teste de Tukey $(\alpha=0,05)$. Resultados: Para a análise de cor do esmalte, todos os grupos clareados diferiram estatisticamente do grupo não clareado. A adição de diferentes concentrações de nHA não interferiu com a eficácia clareadora para o esmalte e dentina. Para o microcisalhamento, não houve diferença entre os grupos. A taxa de falha adesiva do grupo HP 35\% + nHA 10\% foi menor do que o grupo HP 35\% e similar ao controle negativo. Conclusão: a adição de diferentes concentrações de nHA em $\mathrm{PH} 35 \%$ não interferiu na eficácia clareadora do esmalte e da dentina e não afetou a força de adesão do esmalte após o clareamento.

\section{PALAVRAS-CHAVE}

Esmalte; Resistência ao cisalhamento; Clareamento dental. 


\section{INTRODUCTION}

$\mathrm{T}$ he growing concern with aesthetics and the search for the perfect smile have made tooth whitening the treatment of choice for the removal of intrinsic and extrinsic stains. This treatment is considered relatively safe, effective and easy to perform [1]. Although tooth whitening is an effective treatment, adverse effects can be observed in the teeth, such as a reduction in the bond strength of restorations performed immediately after bleaching [2], increased enamel surface roughness [3] and morphological and structural alterations in the enamel [4] and dentin [5].

These changes are attributed to hydrogen peroxide-based agents that modify the organic and inorganic composition of the enamel [4]. Some remineralizing components, such as fluoride, calcium, amorphous calcium phosphate and hydroxyapatite are used to minimize adverse effects of bleaching treatments on the enamel [6]. These components are added in the bleaching gel to prevent demineralization of the enamel during bleaching and also to prevent or decrease dental sensitivity reported by many patients during and after bleaching treatment [7].

Hydroxyapatite $\left(\mathrm{Ca}_{10}\left(\mathrm{PO}_{4}\right)_{6}(\mathrm{OH})_{2}\right)$ is a polyvalent ceramic that is biocompatible with human bone, skin and gingiva tissues and is found in tooth enamel in the form of crystals [8]. Synthetic hydroxyapatite mimics the morphology, composition and nano-dimensions of natural enamel apatite [8], and when reduced to nanomethane size, it can adhere to the surface of the tooth to cover grooves and pores on the enamel [9]. Due to the above characteristics, it can be used widely in dentistry for purposes such as protecting enamel caries, recurrent cavities and restored cavities; sealing grooves, pits and fissures in primary and permanent teeth and balancing the mineral loss caused by bleaching treatments [10]. Thus, hydroxyapatite has been associated with several dental products such as dentifrices, dentin adhesives, desensitizing agents and bleaching agents [10].

When added to bleaching gels, hydroxyapatite can increase the $\mathrm{pH}$ value due to its alkalinity, thus accelerating the formation of free radicals and facilitating the bleaching process [11]. In literature, it was also observed that the hydroxyapatite associated with hydrogen peroxide produces a greater bleaching effect when compared to the application of only hydrogen peroxide [12]. The hydroxyapatite associated with the bleaching gel also can prevent and minimize the loss of enamel mineral content during bleaching [13] and decrease demineralization by preventing the loss of enamel hardness [6].

The association of hydrogen peroxide with nanohydroxyapatite (nHA) may correspond to an innovative option to reduce post-bleaching demineralization; however, there are no studies that assess the effects of this association on bond strength and deep dentin whitening efficacy. Thus, this in vitro study evaluated the influence of $35 \%$ hydrogen peroxide (HP) containing different concentrations of $\mathrm{nHA}$ on the effectiveness of dental bleaching (superficial enamel and deep dentin) and enamel bond strength.

\section{MATERIALS AND METHODS}

\section{Specimens preparation}

Fifty freshly extracted bovine teeth were stored at $0.1 \%$ thymol. In a low-speed hand piece under constant water irrigation, the crowns were separated in the dentin-enamel junction using a double-faced diamond disc (KG Sorensen, Barueri, SP, Brazil). The blocks (5.0 $\mathrm{mm} \times 5.0 \mathrm{~mm}$ ) were obtained from the middle third of the buccal surface using a metallographic cutting machine (Isomet 1000, Buehler) with diamond disc ( 4 " $\times 012 \times 1 / 2$, Buehler, Illinois, USA). These blocks were planned and polished 
with the silicon carbide sandpaper granulation \#600, \#1200 and \#2000. Subsequently, the enamel surface was polished with felts (TOP, RAM and SUPRA - Arotec, Cotia, SP, Brazil) associated with diamond pastes ( 1 and $1 / 4 \mu \mathrm{m}$ ) to give the standard final thickness of $2 \mathrm{~mm}$ (1 $\mathrm{mm}$ of enamel and $1 \mathrm{~mm}$ of dentin) and patterned surface. All specimens were placed in an ultrasonic machine for 10 minutes (Marconi, Piracicaba, São Paulo, SP, Brazil) during all stages of specimens confection. The specimens were marked with a diamond bur (\#1012, KG Sorensen, Barueri, SP, Brazil) in the side of each block to standardize the sample position in the spectrophotometer (Konica Mi $\neg$ nolta CM 700d, Japan).

\section{Treatments Groups}

The initial $L^{*}$ value of each sample was used to stratify and allocate specimens into into 5 groups $(\mathrm{n}=10)$, in according to bleaching protocol:

- Negative Control: No bleaching,

- 35\% HP: Dental bleaching with 35\% hydrogen peroxide (positive control)

- 35\% HP + 5\% nHA: Dental bleaching with $35 \%$ hydrogen peroxide with added 5\% nanohydroxyapatite

- 35\% HP + 10\% nHA: Dental bleaching with $35 \%$ hydrogen peroxide with added 10\% nanohydroxyapatite,

- 35\% HP + 15\% nHA: Dental bleaching with $35 \%$ hydrogen peroxide with added 15\% nanohydroxyapatite

The $\mathrm{pH}$ values of each gel used are available in Table I.
Table I - pH value of the bleaching gels immediately after manipulation and after 15 minutes of manipulation

\begin{tabular}{|ccc|}
\hline whitening gel & pH time & pHafter 15 minutes \\
\hline $35 \% \mathrm{HP}^{*}$ & 6.23 & 5.52 \\
\hline $35 \% \mathrm{HP}+5 \% \mathrm{nHA} \mathrm{A}^{* *}$ & 6.34 & 5.60 \\
\hline $35 \% \mathrm{HP}+10 \% \mathrm{nHA}$ & 6.41 & 5.64 \\
\hline $35 \% \mathrm{HP}+15 \% \mathrm{nHA}$ & 6.81 & 5.73 \\
\hline \multicolumn{2}{|c|}{${ }^{*}$ Hidrogen Peroxide; ** Nanohydroxyapatite } \\
\hline
\end{tabular}

\section{Bleaching Procedure}

For all groups, bleaching treatments were performed for three sessions, with an interval of 7 days between each session. A bleaching gel with 35\% hydrogen peroxide (Whiteness HP, FGM, Joinville, Brazil) was applied according to the manufacturer that consists of 3 times for 15 min for session. For the nHA groups the nanohydroxyapatite (Sigma Aldrich Co., Madrid, Spainwas) was weighed using an analytical balance (Shimadzu AUW 220 d, Kyoto, Japan) in accordance to the percentage for each group and was incorporated into the whitening gel and immediately applied to the specimens. All the days of experiment, the specimens were stored in artificial saliva $(1,5 \mathrm{mM}$ de $\mathrm{Ca} ; 0,9 \mathrm{mM}$ de PO4 e KCl $150 \mathrm{mM}$ in Tris buffer $20 \mathrm{mM}$, pH $7,0)$ (Queiroz, 2008) at $37^{\circ} \mathrm{C}$ and renewed daily.

\section{Color Measurements}

The color analysis of the enamel surface was done initially to randomize the specimens between the groups. The specimens were positioned in a sample port, and reading of enamel was performed using the Konica Minolta spectrophotometer CM 700d (Japan) under standard ambient light (GTI Graphic Technology Inc., Newburg, NY USA). The device was calibrated according to the manufacturer's instructions and the results obtained and quantified in three coordinates of the CIE $\mathrm{L}^{*} \mathrm{a} * \mathrm{~b}$. In the color space, $\mathrm{L}$ * indicates lightness 
( $\mathrm{L}+=$ lightness and $\mathrm{L}-=$ darkness), the $\mathrm{a}^{*}$ coordinate represents the red/green range $\left(a^{*}\right.$ $+=$ redness and $\mathrm{a}^{*}-=$ greenness $)$ and the $b^{*}$ coordinate represents for the yellow/blue range $\left(\mathrm{b}^{*}+=\right.$ yellowness and $\mathrm{b}^{*}-=$ blueness). Then, the results of the initial color analysis were tabulated and the specimens were divided between the groups in order to reduce the standard deviation between them.

Color analysis after bleaching treatment was performed on the enamel surface and the opposite dentin [14]. The purpose of the dentin evaluation was to verify the penetration of the whitening gel into the $2 \mathrm{~mm}$ specimen $(1 \mathrm{~mm}$ of enamel and $1 \mathrm{~mm}$ of dentin) and to elucidate the whitening efficacy associated with this penetration. Reading times were initial (baseline) and 24 after the third bleaching session. Color analysis was performed in the same manner as described above. The differences in the $\mathrm{L}^{*}, \mathrm{a}^{*}$ and $b^{*}$ values between initial (baseline) and final (24 after the third bleaching session) were expressed $(\Delta \mathrm{L}, \Delta \mathrm{a}, \Delta \mathrm{b})$ and any color change was calculated using the following expression: $\Delta \mathrm{E}=\left[\left(\Delta \mathrm{L}^{*}\right) 2+\left(\Delta \mathrm{a}^{*}\right) 2+\left(\Delta \mathrm{b}^{*}\right) 2\right] 1 / 2$.

\section{Microshear Bond Strength Test:}

The specimens were restored $24 \mathrm{~h}$ after bleaching. All products were used according to the manufacturer's recommendations. All enamel surfaces were etched using phosphoric acid 35\% (Ultra Etch - Ultradent Products Inc, South Jordan, UT, USA) for $30 \mathrm{~s}$, rinsed for 15 seconds and dried for 10 seconds. Etch-andrinse bonding agent (Single Bond, 3M ESPE, St. Paul, MN, USA) was applied to the specimen surface in two coats by a microbrush, air dried with air spray for five seconds and light-cured for 20 seconds from one-millimeter distance using a third generation LED source (VALO, Ultradent, Itaici-Indaiatuba, SP, Brazil) at high power mode, with an irradiance of $1400 \mathrm{~mW} /$ $\mathrm{cm} 2$ for $20 \mathrm{~s}$. Subsequently, the enamel received a composite resin restoration (Filtek Z350XT Flowable A3 shade, 3M ESPE), using a matrix of perforated pasta (Furadinho 6, Pastifício Santa Amália, Machado, Minas Gerais, Brazil) that was $1 \mathrm{~mm}$ in height and with a $1.15 \mathrm{~mm}$ internal diameter. The photoactivation of the composite was also performed using a third generation LED source (VALO, Ultradent, Itaici-Indaiatuba, SP, Brazil) for 20 s. $24 \mathrm{~h}$ after the restorative procedure, the micro-shear test and the fracture pattern analysis were performed.

\section{Fracture pattern analysis}

The fracture pattern of the specimens was analyzed in a stereoscopic 50-fold increase (Leica Microsystems, Wetzlar, Germany), and classified in: adhesive fracture, when the fracture occurred at the interface; cohesive in resin fracture; cohesive in dentin and mixed fracture, encompassing two or more types of fractures. The data obtained in the fracture pattern evaluation were analyzed by frequency distribution (Figure I).

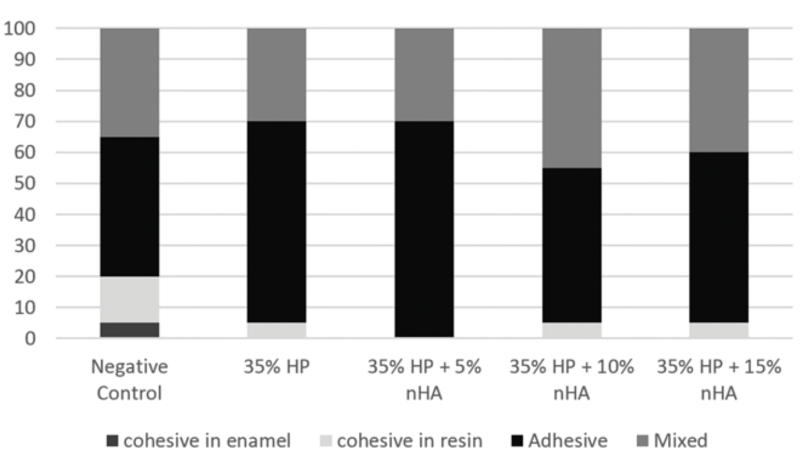

Figure I - Percentage of fracture pattern according to group.

\section{Statistical Analysis}

After exploratory analysis using the SAS software (Release 9.1, 2003, SAS Institute Inc, Cary, NC, USA), the data of the color analysis $\left(\Delta \mathrm{L}^{*}\right.$, $\Delta \mathrm{a}^{*}, \Delta \mathrm{b}^{*}$ and $\left.\Delta \mathrm{E}\right)$ and microshear bond strength test were subjected to one-way analysis of variance (ANOVA), followed by the Tukey test, at a 5\% level of significance. 


\section{RESULTS}

- Color analysis of enamel

For the enamel color analysis, comparing the treatments, there was a statistically significant difference for $\Delta \mathrm{L}(\mathrm{p}<0.0001) \Delta \mathrm{a} *(\mathrm{p}<0.0001), \Delta \mathrm{b}^{*}$ $(\mathrm{p}<0.0001)$ and $\Delta \mathrm{e}^{*}(\mathrm{p}<0.0001)$.

Based on color analysis of enamel (Table II), the positive control (35\% HP) differed statically from negative control for the $\Delta \mathrm{L}^{*}, \Delta \mathrm{a}^{*}, \Delta \mathrm{b}^{*}$ and $\Delta \mathrm{E}$ values with increasing $L^{*}$ values and decreasing $b^{*}$ values. All bleached groups were statistically different from negative control for the $\Delta \mathrm{L}^{*}, \Delta \mathrm{a}^{*}, \Delta \mathrm{b}^{*}$ and $\Delta \mathrm{E}$ values. There was no statistically significant difference between the positive control and the nHA groups. For groups with nHA, there was no statistical difference between them.

Table II - Mean (standard deviation) for $\Delta \mathrm{L}, \Delta \mathrm{a}, \Delta \mathrm{b}$ and $\Delta \mathrm{E}$ based on treatment group $(n=10)$ for enamel.

\begin{tabular}{ccccc} 
Group & $\Delta \mathrm{L}$ & $\Delta \mathbf{a}$ & $\Delta \mathbf{b}$ & $\Delta \mathrm{E}$ \\
\hline $\begin{array}{c}\text { Negative } \\
\text { Control }\end{array}$ & $-0.62(1.06) \mathrm{b}$ & $-0.08(0.56) \mathrm{a}$ & $0.42(2.56) \mathrm{a}$ & $2.55(1.18) \mathrm{b}$ \\
$35 \% \mathrm{HP}$ & $4.00(1.26) \mathrm{a}$ & $-0.92(0.50) \mathrm{b}$ & $-6,70(1.69) \mathrm{b}$ & $7.88(2.05) \mathrm{a}$ \\
\hline $35 \% \mathrm{HP}+$ & $3.34(1.24) \mathrm{a}$ & $-1.32(0.64) \mathrm{b}$ & $-6,17(1.68) \mathrm{b}$ & $7.26(1.71) \mathrm{a}$ \\
$5 \% \mathrm{nHA}$ & & & & \\
$35 \% \mathrm{HP}+$ & $2.44(1.97) \mathrm{a}$ & $-1.05(0.41) \mathrm{b}$ & $-6,27(2.74) \mathrm{b}$ & $6.21(2.30) \mathrm{a}$ \\
$10 \% \mathrm{nHA}$ & & & & 5.95 \\
$35 \% \mathrm{HP}+$ & $2.78(1.62) \mathrm{a}$ & $-0.74(0.44) \mathrm{ab}$ & $-5,02(1.94) \mathrm{b}$ & $(2.12) \mathrm{a}$ \\
\hline $15 \% \mathrm{nHA}$ & & & &
\end{tabular}

Different letters indicate significant difference among different groups in the same column $(p \leq 0.05)$.

\section{- Color analysis of deep dentin}

The results of dental bleaching effectiveness for deep dentin are available in Table III. Comparing the treatments, there was a statistically significant difference for $\Delta \mathrm{L}(\mathrm{p}<0.0001) \Delta \mathrm{a} *(\mathrm{p}<0.0001), \Delta \mathrm{b} *$ $(\mathrm{p}=0.0009)$ and $\Delta \mathrm{e}^{*}(\mathrm{p}=0.0003)$.

The positive control differed statically from negative control for the $\Delta \mathrm{L}^{*}, \Delta \mathrm{a}^{*}, \Delta \mathrm{b}^{*}$ and $\Delta \mathrm{E}$ values $(p<0.05)$. All groups with nHA differed from the negative control in the $\Delta \mathrm{L} *, \Delta \mathrm{a} *, \Delta \mathrm{b} *$ and $\Delta E$ values $(\mathrm{p}<0.05)$. There was no statistically significant difference between the positive control and the nHA groups $(\mathrm{p}>0.05)$. For groups with nHA, there was no statistical difference between them $(\mathrm{p}>0.05)$.

Table III - Mean (standard deviation) for $\Delta \mathrm{L}, \Delta \mathrm{a}, \Delta \mathrm{b}$ and $\Delta \mathrm{E}$ based on treatment group $(n=10)$ for deep dentin.

\begin{tabular}{ccccc} 
Group & $\Delta \mathrm{L}$ & $\Delta \mathrm{a}$ & $\Delta \mathrm{b}$ & $\Delta \mathrm{E}$ \\
\hline $\begin{array}{c}\text { Negative } \\
\text { Control }\end{array}$ & $0.07(1.38) \mathrm{c}$ & $-0.23(0.81) \mathrm{a}$ & $-0.83(3.22) \mathrm{a}$ & $3.12(1.72) \mathrm{b}$ \\
$35 \% \mathrm{HP}$ & $4.40(1.84) \mathrm{ab}$ & $-1.89(0.72) \mathrm{b}$ & $-6.44(3.34) \mathrm{b}$ & $8.18(3.48) \mathrm{a}$ \\
\hline $35 \% \mathrm{HP}+$ & $4.63(1.43) \mathrm{a}$ & $-2.77(0.86) \mathrm{b}$ & $-6.60(3.73) \mathrm{b}$ & $8.80(3.39) \mathrm{a}$ \\
$5 \% \mathrm{nHA}$ & & & & \\
$35 \% \mathrm{HP}+$ & $3.35(1.63) \mathrm{ab}$ & $-2.14(0.66) \mathrm{b}$ & $-5.64(2.88) \mathrm{b}$ & $7.30(2.59) \mathrm{a}$ \\
$10 \% \mathrm{nHA}$ & & & & \\
$35 \% \mathrm{HP}+$ & $2.59(1.09) \mathrm{b}$ & $-1.96(0.85) \mathrm{b}$ & $-4.36(2.57) \mathrm{b}$ & $6.12(2.15) \mathrm{a}$ \\
$15 \% \mathrm{nHA}$ & & & &
\end{tabular}

Different letters indicate significant difference among different groups in the same column ( $p \leq 0.05)$.

\section{- Microshear bond strength analysis}

The microshear bond strength values are available in Table IV. There were no statistically significant differences between groups $(\mathrm{p}=0,3861)$. The negative control group showed lower adhesive failure rate $(45 \%)$ and high cohesive failure rate in resin (15\%) when compared to positive control (adhesive - 65\%; cohesive resin - 5\%). The 35\% $\mathrm{HP}+10 \%$ nHA group showed adhesive failure rate $(50 \%)$ similar to negative control $(45 \%)$ and lower when compared to bleached groups (positive control-65\%; 35\% HP + 5\% nHA-70\%; 35\% HP + $15 \%$ nHA- 55\%) (Figure I).

Table IV - Mean (standard deviation) for microshear bond strength (MPa).

\begin{tabular}{|c|c|}
\hline Group & Microshear Strength (MPa) \\
\hline No bleaching & $16.57(4.31) \mathrm{a}$ \\
\hline $35 \% \mathrm{HP}$ & $15.83(5.88) \mathrm{a}$ \\
\hline $35 \% \mathrm{HP}+5 \% \mathrm{nHA}$ & $13.60(3.31) \mathrm{a}$ \\
\hline $35 \% \mathrm{HP}+10 \% \mathrm{nHA}$ & $12.65(3.09) \mathrm{a}$ \\
\hline $35 \% \mathrm{HP}+15 \% \mathrm{nHA}$ & $15.02(6.89) \mathrm{a}$ \\
\hline
\end{tabular}

Means followed by same letters did not differ from each other (p» 0.05). 


\section{DISCUSSION}

According to the results observed in this study, the addition of different concentrations of nHA to $35 \%$ hydrogen peroxide showed whitening efficacy comparable to $35 \%$ hydrogen peroxide without nHA. For the microshear bond strength test, the addition of nHA to the bleaching agent did not affect the enamel bond strength, but the 35\% HP associated with 10\% nHA showed fewer adhesive failures.

All the groups that were subjected to dental bleaching had a color change, except the negative control group. The addition of nHA at 35\% HP promoted an increase in alkalinity (Table I) immediately after its manipulation. Alkalinity can accelerate the formation of free radicals facilitating the bleaching procedure [11]. Despite the increased $\mathrm{pH}$ value for the enamel, the addition of nHA to the bleaching gel showed whitening efficacy comparable to HP without nHA. A similar result was also reported in the literature, where the addition of hydroxyapatite did not interfere with bleaching efficacy $[6,13]$. Synthetic hydroxyapatite has particles with dimensions similar to those found in enamel and could react with natural hydroxyapatite because its chemical structure is similar to the tooth structure [15]. Nanoand microhydroxyapatite materials were applied to the enamel surface, as a suspension or dissolvable polymer films, and whitening effects and durability against hydrodynamic shearing forces with FE-SEM observations were previously reported by Dabanoglu et al. [15]. After application, hydroxyapatite is deposited on the enamel, creating a layer without chemically affecting the dental tissue [16].

For enamel surface, the concentrations of $5 \%, 10 \%$ and $15 \%$ of nHA did not affect the effectiveness of the bleaching treatments, as all bleaching groups demonstrated increasing $L^{*}$ values and decreasing $b *$ values, while also presenting $\Delta \mathrm{E}$ values that were statistically similar to the positive control (35\% hydrogen peroxide without nHA). The presence of nHA did not interfere with the substrate characteristics and the hydrogen peroxide reaction. In vitro $[6,13,17]$ and in vivo studies [18] reported the use of varying concentrations of hydrogen peroxide mixed with varying concentrations of hydroxyapatite in home or in-office bleaching. Regardless of the whitening agent, technique or concentration of hydroxyapatite, these studies also showed that hydroxyapatite did not interfere in whitening effectiveness. According to Jiang et al. [13], the concentration of nHA did not interfere in tooth whitening because the whitening ability of HP associated with nHA should be mainly attributed to HP. Hydrogen peroxide oxidizes a wide variety of organic and inorganic compounds [19]. Hydrogen peroxide can form a number of different active oxygen species depending on reaction conditions, including temperature, $\mathrm{pH}$, light and presence of transition metals [20]. Associated with this, the hydroxyapatite can increase the $\mathrm{pH}$ value due to its alkalinity, thus accelerating the formation of free radicals and facilitating the bleaching process [11]. Under alkaline conditions, hydrogen peroxide bleaching generally proceeds via the perhydroxyl anion $\left(\mathrm{Ho}_{2}\right)$.

D'Arce et al. [14] showed that the penetration and bleaching effectiveness of the bleaching agent may be associated with the composition of the gel used. To evaluate if the addition of different concentrations of nHA in the 35\% HP was able to affect penetration and bleaching effectiveness, a color analysis of the opposite dentin was performed. For the color of the dentin, it was observed that 35\% HP statistically differed from the negative control (no bleaching). The most accepted theory about tooth whitening suggests that hydrogen peroxide diffuses through the enamel to the dentin, where it reacts with the chromogens responsible for the color change [21] through an oxidation reaction. This diffusion is favored due to the low molecular weight of hydrogen peroxide and its by-products, facilitating the course of this 
molecule by the mineralized dental tissues [22] and by the specific chemical affinity of hydrogen peroxide with each one of these tissues [23]. Thus, the pigment molecules become small enough to be removed from the dental structure through diffusion, which indirectly promotes the reduction of light absorption, leaving the tooth apparently lighter [24].

Although the values of the enamel and dentin color analysis showed the absence of differences between the bleached groups, there is a tendency for a decrease in $\Delta \mathrm{E}$ values with the increase of nHA concentration. Statistics is very importante to be applied to the data, but this tendency shows some relation to the concentration use. We believe that this may have happened because of the calcium of the hydroxyapatite incorporated into the gel. The bleaching agents may be more calcium saturated momentarily than the enamel surface, and therefore the calcium ionic released from the gel to the substrate [25] may make the transitional microporosity formation more difficult, leading to less effective bleaching in deeper portions of the tooth [14].

Despite this trend in $\Delta \mathrm{E}$ values, statistically, the whitening mechanism was not affected by nHA because the results show that different concentrations of nHA in the bleaching gel did not interfere with bleaching efficacy. This result is important because essentially the color of the teeth is determined by the color of the dentin and by the extrinsic and intrinsic coloration [26]. The same result was found by Jiang et al. [13] in which bleaching with 30\% HP did not interfere with bleaching efficacy. According to Joiner et al. [27], light scattering and absorption within dental hard tissues give rise to the intrinsic color of the teeth, and as the enamel is a relatively translucent surface, the properties of dentine are very important to determining the overall tooth color. Thus, in this study the penetration of the bleaching agent and the effectiveness of bleaching in depth were not affected by the addition of nHA at different concentrations.

Regarding the enamel bond strength, the high demand for aesthetic procedures has motivated patients to seek restorative treatments after bleaching treatments. During tooth whitening, oxygen free radicals are delivered from the bleaching agents through the enamel surface. Thus, oxygen, hydroxyl or perhydroxyl ions remain trapped in dentinal structures [28], inhibiting the polymerization of composite resin materials [29]. The literature does not indicate the performance of adhesive restorative procedures immediately after bleaching. In this study, there were no statistically significant differences between groups ( $p>0.05)$ for the microshear bond test. A possible explanation for this finding may be the interval given after the end of bleaching. The composite resin restorations were performed $24 \mathrm{~h}$ after bleaching, which may have favored the elimination of residual oxygen. This result corroborates with Unlu et al. [30], who showed that bleaching with $10 \%$ carbamide peroxide did not interfere with the adhesion strength of restorations performed $24 \mathrm{~h}$ after bleaching. Waiting periods ranging from $24 \mathrm{~h}$ to three weeks after bleaching have been recommended before initiating tooth restorations with composite resins to overcome this post bleaching effect on bond strength [31,32]. Also, some studies show that the strength of adhesion to enamel after bleaching is improved when etch-and-rise adhesive systems are used [33-35]. This factor may have contributed to the results found in this study.

The percentage of fracture patterns shows that the negative control had a lower number of adhesive failures when compared to the positive control. The 35\% HP $+10 \%$ nHA group presented a lower adhesive failure rate (50\%), similar to the negative control $(45 \%)$. These results may be explained by deposition of hydroxyapatite on the surface. Sasaki et al. [6] evaluated the use of HA with a bleaching 
agent and showed that hydroxyapatite causes the deposition of minerals, which leads to an increase in the surface roughness of the enamel. This possible increase in enamel roughness and crystal deposition may have favored surface adhesion and resulted in a lower number of adhesive failures for the $35 \% \mathrm{HP}+10 \% \mathrm{nHA}$.

\section{CONCLUSION}

In conclusion, the addition of the nHA in 35\% HP did not interfere with effectiveness of the bleaching in enamel and deep dentin. Although tooth whitening did not affect the bond strength values of restorations made 24 hours after bleaching, the bleaching groups presented higher adhesive failures, but these failures were decreased when the bleaching gel was associated with $10 \%$ nHA.

\section{REFERENCES}

1. LiY.Safety controversies in tooth bleaching. Dent Clin North Am. 2011;55(2):255-63. doi: 10.1016/j.cden.2011.01.003.

2. Alencar MS, Bombonatti JF, Maenosono RM, Soares AF, Wang L, Mondelli RFEEffect of Two Antioxidants Agents on Microtensile Bond Strength to BleachedEnamel. Braz Dent J. 2016 Sep-0ct;27(5):532-536. doi: 10.1590/0103-6440201600757.

3. Vieira-Junior WF,Lima DA, Tabchoury CP, Ambrosano GM, Aguiar FH, Lovadino JR. Effect of Toothpaste Application Prior to Dental Bleaching on Whitening Effectiveness and Enamel Properties. Oper Dent. 2016 JanFeb;41(1):E29-38. doi: 10.2341/15-042-L.

4. Vieira-Junior WF,Ferraz LN, Pini NIP, Ambrosano GMB, Aguiar FHB, Tabchoury CPM, Lima DANL. Impact of toothpaste use against mineral loss promoted by dental bleaching. Operative Denistry in press.

5. Chng HK, Ramli HN, Yap AU, Lim CT. Effect of hydrogen peroxide on intertubular dentine.J Dent. 2005;33(5):363-9.

6. Sasaki RT, Catelan A, Bertoldo Edos S, Venâncio PC, Groppo FC, Ambrosano GM, et al. Effect of $7.5 \%$ hydrogen peroxide containing remineralizing agents on hardness, color change, roughness and micromorphology of human enamel. Am J Dent. 2015 0ct;28(5):261-7.

7. Chen HP, Chang CH, Liu JK, Chuang SF, Yang JY. Efeect of fluoride containing bleaching agents on enamel surface properties. J Dent. 2008 Sep;36(9):71825. doi: 10.1016/j.jdent.2008.05.003. Epub 2008 Jun 24.

8. Generosi A, Rau JV, Rossi VA, Paci B. Crystallization process of carbonate substituted hydroxyapatite nanoparticles in toothpastes upon physiological conditions: an in situ time-resolved X-ray diffraction study. J Mater Sci Mater Med. 2010 Feb;21(2):445-50. doi:10.1007/s10856-009-3905-z. Epub 2009 0ct 16 .
9. Kim BL, Jeong SH, Jang SO, Kim KN, Know HK, Park YD. Whitening effect of toothpastes containing nano-hydroxiapatite. Key Engin Mater. 2006;309(311):541-4.

10. Oliveira M, Mansur HS. Synthetic tooth enamel: SEM characterization of a fluoride hydroxyapatite coating for dentistry applications. Mater Res. 2007;10(2):115-8.

11. Dahl JE, Pallesen U. Tooth bleaching-a critical review of the biological aspects. CritRev Oral Biol Med. 2003;14(4):292-304.

12. Mohd Janurudin J, Ozeki K, Aoki H, Fukui Y. Preparation of a hydroxyapatite and hydrogen peroxide composite for tooth whitening. Biomed Mater Eng. 2007:17(2):69-75.

13. Jiang T, Ma X, Wang Z, Tong H, Hu J, Wang Y. Beneficial effects of hydroxyapatite on enamel subjected to $30 \%$ hydrogen peroxide. J Dent. 2008 Nov;36(11):907-14. doi: 10.1016/j.jdent.2008.07.005. Epub 2008 Sep 2.

14. D'Arce MB, Lima DA, Aguiar FH, Bertoldo CE, Ambrosano GM, Lovadino JR. Effectiveness of dental bleaching in depth after using different bleaching agents. J Clin Exp Dent. 2013 Apr 1;5(2):e100-7. doi: 10.4317/jced.51063.

15. Dabanoglu A, Wood C, García-Godoy F, Kunzelmann KH. Whitening effect and morphological evaluation of hydroxyapatite materials. Am J Dent. 2009 Feb;22(1):23-9.

16. Yamagishi K, Onuma K, Suzuki T, Okada F, Tagami J, Otsuki M, et al. Materials chemistry: A synthetic enamel for rapid tooth repair. Nature. $2005 \mathrm{Feb}$ 24;433(7028):819

17. Khoroushi M, Shirban F, Kaveh S, Doustfateme S. Effect of three nanobiomaterials on microhardness of bleached enamel. Restor Dent Endod. 2016 Aug;41(3):196-201. doi: 10.5395/rde.2016.41.3.196.

18. Vano M, Derchi G, Barone A, Genovesi A, Covani U. Tooth bleaching with hydrogen peroxide and nano-hydroxyapatite: a 9-month follow-up randomized clinical trial. Int J Dent Hyg. 2015 Nov;13(4):301-7. doi: 10.1111/ idh.12123.

19. Joiner A. The bleaching of teeth: a review of the literature.J Jent. 2006 Aug;34(7):412-9.

20. Hove-Grant M, editor. Encyclopedia of chemical technology. 4 ed. New York: John Wiley and Sons; 1992. p.13-5.

21. Ontiveros JC, Paravina RD. Color change of vital teeth exposed to bleaching performed with and without light. J Dent. 2009 Nov;37(11):840-7. doi: 10.1016/j.jdent.2009.06.015. Epub 2009 Jun 30.

22. Eimar H, Siciliano R, Abdallah MN, Nader SA, Amin WM, Martinez PP, et al Hydrogen peroxide whitens teeth by oxidizing the organic structure. J Dent. 2012;40:e25-33. doi: 10.1016/j.jdent.2012.08.008.

23. Ubaldini AL, Baesso ML, Medina Neto A, Sato F, Bento AC, Pascotto RC. Hydrogen peroxide diffusion dynamics in dental tissues. J Dent Res. 2013 Jul;92(7):661-5. doi: 10.1177/0022034513488893. Epub 2013 Apr 30.

24. Sueliman M. An overview of bleaching techniques: I. History, chemistry, safety and legal aspects. Dent Update. 2004 Dec;31(10):608-10, 612-4,616.

25. Gao XJ, Elliott JC, Anderson P.Scanning and contact microradio-graphic study of the effect of degree of saturation on the rate of ename demineralization. J Dent Res. 1991;70(10):1332-7.

26. Watts A, Addy M. Tooth discolouration and staining: a review of the literature. Br Dent J. 2001Mar 24;190(6):309-16.

27. Joiner A. Tooth colour: a review of the literature. J Dent. 2004;32 Suppl 1:3-12.

28. Comlekoglu ME, Gokce B, Kaya AD, Turkun M, Ozpinar B. Reversal of reduced bond strength after bleaching. Gen Dent. 2010 May-Jun;58(3):258-63; quiz 264-5. 
29. Vidhya S, Srinivasulu S, Sujatha M, Mahalaxmi S. Effect of grape seed extract on the bond strength of bleached enamel. Oper Dent. 2011;36(4):433-38. doi: 10.2341/10-228-L.

30. Unlu N, Cobankara FK, Ozer F. Effect of elapsed time following bleaching on the shear bond strength of composite resin to enamel. J Biomed Mater Res B Appl Biomater. 2008;84(2):363-8.

31. Uysal T, Basciftci FA, Uşümez S, SariZ, Buyukerkmen A. Can previously bleached teeth be bonded safely? Am J Orthod Dentofacial Orthop. 2003 Jun;123(6):628-32.

32. Cavalli V, Giannini M, Carvalho RM. Effect of carbamide peroxide bleaching agents on tensile strength of human enamel. Dent Mater. 2004 Oct;20(8):733-9
33. Adebayo OA Burrow MF Tyas MJ. Effects of conditioners on microshear bond strength to enamel after carbamide peroxide bleaching and/or casein phosphopeptide-amorphous calcium phosphate (CPP-ACP) treatment. J Dent. 2007 Nov;35(11):862-70.

34. Moule CA, Angelis F, Kim GH, Le S, Malipatil S, Foo MS, et al. Resin bonding using an all-etch or self-etch adhesive to enamel after carbamide peroxide and/or CPP-ACP treatment. Aust Dent J. 2007 Jun;52(2):133-7.

35. Gurgan S, Alpaslan T, Kiremitci A, Cakir FY, Yazici E, Gorucu J. Effect of different adhesive systems and laser treatment on the shear bond strength of bleached enamel. J Dent. 2009 Jul;37(7):527-34. doi:10.1016/j. jdent.2009.03.012. Epub 2009 Apr 28.

\section{Débora Alves Nunes Leite Lima}

\section{(Corresponding address)}

Department of Restorative Dentistry, Piracicaba Dental School, UNICAMP. Av. Limeira, 901 Areião P.O. Box 52 Zip code 13414-903 Piracicaba, SP, Brazil.

Phone: +55 19 2106-5337

Fax: +55 19 3421-0144

E-mail: dalima@unicamp.br

Date submitted: 2017 Nov 16

Accept submission: 2018 Jan 12 